\title{
DOKTRIN TINDAKAN HUKUM ADMINISTRASI NEGARA MEMBUAT KEPUTUSAN (BESCHIKKING)
}

\author{
Herman \\ Fakultas Ilmu Sosial Universitas Negeri Makassar \\ Email : hermanhrm17@ymail.com \\ Hendry Julian Noor \\ Fakultas Hukum Universitas Gadjah Mada \\ Email : hendryjuliannoor@yahoo.co.id
}

\begin{abstract}
ABSTRAK
Keputusan administrasi negara merupakan tindakan hukum sepihak oleh pemerintah berdasarkan hukum publik. Kewenangan tindakan hukum berdasarkan hukum publik merupakan kewenangan istimewa (bijzonderrecht) pemerintah bertindak di dalam hukum. Pengertian istimewa oleh karena kewenangan itu diberikan oleh hukum publik untuk menjalankan pelayanan kepada masyarakat selaku badan penguasa. Berbeda dengan tindakan hukum privat yang diberikan oleh hukum perdata (objectieverecht) kepada para subyek hukum (subjectieverecht). Tindakan itu merupakan tindakan hukum biasa yang tidak terkait dengan suatu hal "khusus atau istimewa".

Sifat tindakan hukum dalam hal keputusan administrasi negara adalah konkrit, individual, dan final. Konkrit adalah kualifikasi tindakan hukum yang berkenaan dengan suatu peristiwa hukum tertentu, individual diartikan sebagai suatu tindakan hukum yang ditujukan kepada seseorang atau badan hukum tertentu yang dituju oleh keputusan administrasi negara, dan final yang berarti, bahwa keputusan itu tidak lagi membutuhkan peneguhan atau persetujuan dari pejabat administrasi negara yang lainnya, sehingga dengan demikian telah menimbulkan suatu akibat hukum. Kewenangan yang didistribusikan oleh undangundang berdasarkan kewenangan atribusi, delegasi, dan mandat oleh pemerintah selaku badan penguasa diberikan kepada jabatan atau organ di dalam badan administrasi negara. Pelaksanaan kewenangan secara nyata tindakan hukum membuat keputusan administrasi negara dilakukan oleh pejabat administrasi negara.
\end{abstract}

Kata Kunci: Keputusan administrasi negara, abstraksi dan konseptualisasi doktrin.

\section{ABSTRACT}

State administrative decisions are unilateral legal action by the government based on public law. The authority of legal action by public law is the authority of special (bijzonderrecht) government acted within the law. Peculiar sense therefore that the authority granted by public law to carry out the public service as the ruling body. In contrast to private legal action given by civil law (objectieverecht) to the legal subject (subjectieverecht). The action was an ordinary legal action that is not associated with something "special or privileged".

The nature of the legal action in the case of the state administration's decision is a concrete, individual and final. Concrete is a qualified legal action relating to an 
event specific law, the individual is defined as a legal action which is addressed to an individual or legal entities designated by the decision of the state administration, and final, which means that the decision was no longer in need of affirmation or approval of officers administration of other countries, and thus has caused a legal consequence. The authority is distributed by legislation based on the authority of attribution, delegation, and mandated by the government as the ruling body or organ given to positions in the state administration bodies. Implementation of real authority to make legal action the state administrative decisions made by officials of the state administration.

Keywords: Decision of state administration, abstraction and conceptualization doctrine.

\section{Pendahuluan}

Kewenangan

pemerintah

administrasi

kewenangan

bertindak

hukum

merupakan

diberikan

berdasarkan suatu ketentuan hukum

positif. Dimensi tindakan hukum pemerintah dapat dibagi dalam tindakan hukum (rechtshandeling)(tindakan hukum pemerintah dibagi atas tindakan hukum publik dan tindakan hukum privat), dan tindakan yang bukan tindakan hukum (fetelijkhandeling) (tindakan nyata merupakan suatu tindakan yang tidak ada relevansinya dengan hukum, namun demikian, ulasan dalam tulisan ini tidak berpretensi untuk mengulas perihal tindakan nyata pemerintah ). Kewenangan sebagaimana yang diberikan oleh ketentuan hukum positif merupakan wujud dari kewenangan atribusi, delegasi, dan mandat. Kewenangan (gezakt) merupakan kekuasaan yang diberikan oleh ketentuan hukum publik terdiri atas wewenang (bevoegdheden) dalam melaksanakan tugas dan fungsi publik. kewenangan dalam hukum positif kita, diterjemahkan sebagai urusan pelayanan publik.
Ketentuan hukum positif badan pemerintah dalam melakukan tindakan hukumnya, merupakan suatu ketentuan yang berdasarkan pada hukum publik, oleh karenanya tindakan tersebut hanya dapat dilakukan oleh pemerintah (tindakan hukum istimewa, bijzonderrecht). Tindakan hukum pemerintah selaku badan penguasa, merupakan tindakan hukum sepihak yang tidak memerlukan persetujuan dari pihak lain, diambil berdasarkan kemauan dan keinginan sepihak dari pemerintah, serta sesuai dengan kewenangan yang melekat padanya. Tindakan demikian, adalah rangka melaksanakan tugas dan fungsi pemerintahan sebagai bentuk pelayanan kepada masyarakat.

Pada dasarnya, hukum publiklah yang memberikan kewenangan kepada pemerintah untuk bertindak, sebagai perwujudan atau pelaksanaan dari ketentuan konstitusional negara (tujuan politik negara) (UUD 1945). Pembagian kekuasaan dalam konstitusi Indonesia, memberikan kewenangan (yuridikitas) kepada pemerintah untuk melaksanakan secara konkrit tujuan dari politik negara. Pelaksanaan tujuan politik negara dalam konstitusi, oleh pemerintah 
diatur lebih lanjut melalui peraturan organik (undang-undang), antara Dewan Perwakilan Rakyat (DPR) bersama-sama dengan pemerintah. Substansi peraturan organik ini, mengandung tujuan pelaksanaan politik hukum negara berdasarkan konstitusi yang konkritisasi pelaksanaannya diatur lebih lanjut melalui undang-undang.

Selanjutnya, undang-undang memberikan kewenangan kepada pemerintah untuk melaksanakan substansi dari tujuan politik hukum negara. Dalam bahasa hukum administrasi negara, hal ini diterjemahkan sebagai tugas dan fungsi pemerintah yang berkenaan dengan pelayanan masyarakat. Salah satu wujud dari pelaksanaan kewenangan pemerintah, adalah tindakan hukum pemerintah dalam membuat keputusan administrasi negara. Keputusan administrasi negara merupakan salah satu bentuk pelayanan kepada masyarakat yang menunjuk secara individual bentuk pelayanan pemerintah.

Ketentuan hukum positif, mengkualifikasikan keputusan tata usaha negara sebagai penetapan tertulis (pengertian tertulis menunjuk isinya, bukan bentuknya, yang berguna untuk mempermudah dalam hal pembuktian. Sehingga, memo atau nota dapat memenuhi syarat tertulis, dan merupakan suatu keputusan tata usaha negara, apabila telah jelas organ tata usaha negara yang membuatnya, maksud dan perihal isi tulisan, dan kepada siapa tulisan ditujukan serta hal apa yang ditetapkan di dalam keputusan itu) yang dikeluarkan oleh badan atau pejabat tata usaha negara yang berisi tindakan hukum (perbuatan yang menimbulkan hak dan kewajiban kepada seseorang atau badan hukum perdata. Dalam sambutan pemerintah atas persetujuan DPR terhadap Rancangan Undang-Undang tentang Peradilan Tata Usaha Negara pada Tanggal 20 Desember 1986, pemerintah berpendapat bahwa pemerintah diberi wewenang untuk melakukan tindakan tata usaha Negara yang dapat dikelompokkan dalam tiga macam perbuatan atau tindakan, yaitu mengeluarkan keputusan (beschikking), mengeluarkan peraturan (regeling), dan melakukan perbuatan materiil (materiele daad). Kompetensi Peradilan Tata Usaha Negara hanya terbatas mengenai mengeluarkan keputusan, Sudarson;1994), Risalah Rapat Proses Pembahasan 5 (lima) Rancangan Undang-Undang Bidang Hukum (Integrated Justice System), pada Rabu 30 Januari 2004 Masa Sidang II Rapat ke 21 Rapat Panitia Kerja (Panja), keterangan Mahkamah Agung yang diwakili oleh Paulus E. Lotulung menyatakan, bahwa Pengadilan Tata Usaha Negara ditujukan pada obyek gugatan berupa keputusan, bukan pada pribadi atau perilaku pejabatnya. Jadi sanksi yang dijatuhkan adalah sanksi kepada keputusan itu, batal atau dinyatakan batal, bukan terhadap orang yang mengambil keputusan tersebut. Lihat dalam Sekretariat Jenderal Dewan Perwakilan Rakyat Republik Indonesia (2008;673) tata usaha negara berdasarkan peraturan perundang-undangan (semua peraturan yang bersifat mengikat secara umum yang dikeluarkan Dewan Perwakilan Rakyat bersama pemerintah, baik pusat, maupun di daerah, termasuk keputusan badan atau pejabat administrasi negara, baik di pusat maupun di daerah yang 
juga mengikat secara umum) yang bersifat konkrit (obyek yang diputuskan tidak abstrak, namun berwujud, tertentu (dapat ditentukan), individual (tertentu baik alamat maupun yang dituju, dan apabila yang dituju lebih dari satu orang, maka tiap-tiap nama orang yang terkena keputusan disebutkan), dan final (telah definitif, sehingga sudah menimbulkan akibat hukum. Keputusan tata usaha negara yang masih memerlukan persetujuan instansi atasan atau instansi lain belum bersifat final, dan belum menimbulkan hak dan kewajiban), serta menimbulkan akibat hukum bagi seseorang atau badan hukum perdata. Pasal 1 ayat (3) UndangUndang Nomor 5 Tahun 1986 tentang Peradilan Tata Usaha Negara, lihat juga Pasal 3 UU No. 5 Tahun 1986 menyebutkan, bahwa apabila badan atau pejabat tata usaha negara tidak mengeluarkan keputusan, padahal merupakan kewajibannya, maka dapat juga diartikan sebagai keputusan tata usaha negara. Penolakan mengeluarkan keputusan tata usaha negara yang dimohonkan, apabila jangka waktu yang ditentukan dalam peraturan perundangundangan dimaksud telah lewat, maka dianggap telah menolak mengeluarkan keputusan tata usaha negara. Apabila peraturan perundang-undangan itu tidak menentukan jangka waktu, maka setelah lewat jangka waktu empat bulan sejak diterimanya permohonan, maka badan atau pejabat tata usaha negara dianggap telah mengeluarkan keputusan penolakan.

Kualifikasi

administrasi negara berdasarkan ketentuan hukum positif, di dalamnya memiliki keterbatasan pemaknaan terhadap keputusan administrasi negara itu sendiri, apalagi apabila dibandingkan dengan pemaknaan doktrinal. Secara historis (lihat risalah sidang UU No. 5 Tahun 1986 tentang Peradilan Tata Usaha Negara), ketentuan normatif hukum positif tentang keputusan administrasi negara, dapat dipahami sebagai perkembangan awal tindakan hukum pemerintah membuat keputusan administrasi negara, yang mana pengujiannya (toetsingrecht) melalui suatu lembaga yang independen (yudikatif). Sehingga, dalam ketentuan hukum positif tidak secara utuh dan komprehensif dapat memberikan kualifikasi terhadap pengertian keputusan administrasi negara. Lahirnya UU No. 30 Tahun 2014 tentang Administrasi Pemerintahan juga tidak menjawab secara utuh dan komprehensif mendalam tentang makna keputusan administrasi negara, justeru melahirkan inkonsistensi pemaknaan keputusan administrasi negara, apabila dilihat dari sudut pandang doktrinal tentang keputusan administrasi negara. UU ini juga mengacaukan antara pengertian keputusan dengan tindakan yang merupakan dua hal yang berbeda.

Sebagai konsekuensi logisnya, dalam praktek sengketa keputusan di peradilan administrasi negara yang cenderung normatif, mengkualifikasikan keputusan administrasi negara secara sempit. Keputusan ini hanya dipahami sebagai suatu keputusan tertulis yang diambil oleh badan (Antara badan dengan pejabat mempunyai posisi hukum yang berbeda. Badan merupakan lembaga pemerintah yang menjalankan tugas dan fungsi pemerintahan dalam pelayanan 
publik. Badan ini tidak dapat secara langsung membuat keputusan administrasi negara, namun melalui pejabat administrasi negaranya. Sedangkan pejabat administrasi negara merupakan individu yang menduduki jabatan yang diberikan kewenangan berdasarkan jabatannya. Lembaga pemerintah merupakan organisasi jabatan-jabatan, atau dapat dikatakan sebagai gabungan jabatanjabatan (complex van ambten) atau pejabat, termasuk tidak melakukan tindakan apapun terhadap suatu permohonan. Suatu tindakan hukum yang berdasarkan pada peraturan perundang-undangan positif. Sifatnya adalah konkrit, individual, dan final.

Seiring dengan dinamika

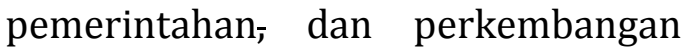
masyarakat pada saat sekarang ini, ketentuan hukum positif yang mengatur tentang keputusan administrasi negara dapat dikatakan tidak memadai lagi. Sehingga dengan demikian, menurut Penulis, penting untuk kembali kepada abstraksi dan konsep-dalam doktrin merupakan salah satu jawabannya.

\section{Permasalahan}

Apakah kualifikasi keputusan administrasi negara berdasarkan doktrin?

\section{Pembahasan}

\section{Keputusan Administrasi Negara Berdasarkan Doktrin}

Sebelum memahami perihal definisi administrasi negara, perlu dipahami terlebih dahulu, bahwa suatu sengketa pendapat yang tidak pernah terurai secara tuntas pada dasarnya adalah mengenai pemberian batasan atau definisi terhadap suatu pengertian. Selama ilmu pengetahuan terus berkembang, maka sesuai sifat alamiahnya, perdebatan mengenai definisi juga seolah tak akan kungjung habis. Pendapat Jacobs Israel de Haan dalam bukunya Rechtskundige Significa, menggambarkan bahwa sangatlah ketat dan sulit untuk merumuskan suatu definisi (Sweens, J.C.M., 1932; Arifin P. Soeria Atmadja, 1986).

Kembali kepada administrasi negara, pengertian administrasi negara oleh Dimock \& Dimock adalah sebagai aktifitas-aktifitas negara dalam melaksanakan kekuasaan politiknya. Dalam arti sempitnya, adalah sebagai aktivitas-aktivitas badan eksekutif dan kehakiman, atau khusus aktivitas badan eksekutif saja dalam melaksanakan pemerintahan. Sedangkan Prajudi Atmosudirdjo, mendefinisikan administrasi negara dalam 3 arti, yaitu sebagai aparatur negara, aparatur pemerintah atau sebagai politik (kenegaraan), sebagai fungsi atau beraktivitas melayani pemerintah, yakni sebagai kegiatan pemerintah operasional, dan sebagai proses teknis penyelenggaraan undang-undang (Bachsan Mustafa ;2001).

Dengan demikian, dapat diambil kesimpulan bahwa pada dasarnya administrasi negara lebih luas pengertiannya daripada tata usaha, atau tata usaha merupakan salah satu bagian dari arti administrasi. Administrasi negara merupakan pengendalian dan pimpinan dari suatu organisasi yang dijalankan dengan pengembangan organisasi, tata usaha, manajemen untuk mencapai tujuan yang telah ditetapkan terlebih dahulu. Kegiatan ini meliputi perencanaan, pengorganisasian, penggerakan, dan pengawasan. 
Jadi, pada hakikatnya adalah suatu kegiatan atau sikap tindakan yang secara teknis dapat dikatakan sebagai pelaksanaan peranan (functie uitoefening, role playing). Dengan demikian, administrasi negara adalah kegiatan melaksanakan fungsi pemerintahan (overheids functie). Dan oleh karenanya, administrasi negara berhubungan dengan dinamika negara yang dapat diandaikan sedang bergerak (de staat in beweging).

Kegiatan melaksanakan peranan (functie uitoefening, role playing) administrasi negara tentang kegiatan melaksanakan overheids functie adalah termasuk dalam kualifikasi keputusan administrasi negara. Secara historis, keputusan administrasi negara pertama kali diperkenalkan oleh Otto Meyer, dan disebutnya dengan istilah verwaltungsakt. Di Belanda, dikenal dengan nama beschikking, yang mana istilah tersebut diperkenalkan oleh van Vollenhoven dan C. W. van der Port (Murtir Jeddawi ;2012) serta beberapa penulis lainnya, seperti AM. Donner, H.D. van Wijk/Willem Konijnenbelt, dan penulis yang lainnya dianggap sebagai "de vader van het moderne beschikkingsbegrip", (bapak dari konsep beschikking yang modern). Dalam konteks Indonesia, istilah beschikking di Indonesia pertama kali diperkenalkan oleh WF. Prins (Ridwan HR ;2012).

Agar utuh dan komprehensif, di bawah ini akan dikemukakan berbagai doktrin yang memberikan definisi tentang keputusan administrasi negara:

1) S. Prajudi Atmosudirjo (1994;94), menerjemahkan keputusan administrasi negara sebagai perbuatan hukum sepihak yang bersifat administrasi negara, dilakukan oleh pejabat atau instansi penguasa (negara) yang berwenang dan berwajib khusus untuk itu. Syarat utamanya, bahwa tindakan hukum (rechtshandeling) itu harus sepihak (eenzijdig), dan harus bersifat administrasi negara. Artinya realisasi dari suatu kehendak atau ketentuan undang-undang secara nyata kasual dan individual. Selain itu, keputusan administrasi negara dinamakan negatif, apabila bersifat penolakan permohonan warga masyarakat;

2) van der Wel: Suatu perbuatan hukum yang dilakukan oleh suatu alat pemerintah dengan maksud dalam hal konkrit meneguhkan, tanpa turut sertanya kehendak pihak yang lain, suatu hubungan hukum yang telah ada atau untuk menimbulkan suatu hubungan hukum yang baru, atau menolak untuk diteguhkannya suatu hubungan hukum yang telah ada atau ditimbulkannya suatu hubungan hukum baru (Utrecht ;1986;96);

3) Stellinga: alat pemerintah (alat dalam arti kata luas), yang isinya tidak terletak di dalam lapangan pembuatan peraturan, polisi dan pengadilan. Stellinga berpegang pada pembagian kekuasaan (functie-verdeling) (Utrecht ;1986;96);

4) van Poelje: Pernyataan keluar kehendak alat perlengkapan administratif penguasa (pusat maupun daerah), dalam bentuk tertulis yang diberikan berdasarkan kewenangan yang 
sah menurut peraturan hukum tata negara atau hukum administrasi negara, ditujukan kepada pemohon keputusan, pengubahan atau pencabutan suatu hubungan hukum, baik yang belum maupun yang sudah berlaku atau suatu penolakan terhadap permohonan itu (Purbopranoto;1981;10).

5) W.F. Prins: tindakan hukum administrasi negara berdasarkan wewenang yang luar biasa berdasarkan hukum publik, dan dilakukan secara sepihak. Jadi, keputusan merupakan tindakan hukum yang bersifat sepihak dalam bidang pemerintahan oleh suatu badan pemerintah berdasarkan wewenangnya yang luar biasa. Unsur-unsur dari pengertian keputusan oleh Prins, pertama, keputusan sebagai tindakan dalam bidang pemerintahan, ke dua, tindakan hukum keputusan (positif) melahirkan hak dan kewajiban, dan permohonan warga negara kepada administrasi negara supaya suatu tindakan dalam hubungan hukum tidak dilakukan (negatif), sebagai pernyataan tidak berwenang atau tidak berdasarkan hukum, dan sebagai penolakan seluruhnya, ke tiga, sifat hukum publik yang berarti berdasarkan wewenang yang luar biasa-kedudukan antara warga negara dengan badan pemerintah tidak berkedudukan sama, dan ke empat, sebagai tindakan sepihak dari pemerintah (W.F. Prins dan R. Kosim Adisapoetra;1987;3854);

6) Van der Pot: perbuatan hukum dari alat-alat pemerintahan (bestuurs organ), yang merupakan pernyataan kehendaknya dalam suatu peristiwa khusus yang dilakukan dengan maksud mengadakan perubahan dalam hubungan hokum (Philipus M. Hadjon ;2002;141-143);

7) A. M. Donner: suatu perbuatan hukum yang dalam hal istimewa dilakukan oleh suatu alat pemerintahan sebagai alat pemerintahan dan/atau berdasarkan suatu ketentuan yang mengikat dan berlaku umum, dengan maksud menentukan hak dan kewajiban mereka yang tunduk pada suatu tertib hukum, dan penentuan itu diadakan oleh alat pemerintahan itu dengan tidak memperhatikan kehendak mereka yang dikenai penentuan itu (eenzijdig) (Utrecht);

8) H.J. Romeijn: Keputusan adalah suatu pernyataan kehendak yang disebabkan oleh surat permohonan yang diajukan, atau setidak-tidaknya keinginan atau keperluan yang dinyatakan (Beschikking; een wilsverklaring naar aanleiding van een ingediend verzoekschrift, of althans een gebleken wensch ofbehoefte) (Philipus M. Hadjon);

9) C.J.N. Versteden: suatu tindakan hukum publik sepihak dari organ pemerintahan yang ditujukan pada peristiwa konkrit (Eenvoudig geworden een definitie van het begrip beschikking te geven: Een eenzijdige publiekrechtelijke rechtshandeling van een bestuursorgaan gericht op een concreet geval) (Philipus M. Hadjon );

10) J.B.M. ten Berge menyebutnya sebagai beschikking, yaitu 
keputusan hukum publik yang bersifat konkrit dan individual berasal dari organ pemerintahan, didasarkan pada kewenangan publik, dibuat untuk satu atau lebih individu atau berkenaan dengan satu atau lebih perkara atau keadaan. Konsekuensi hukumnya, keputusan itu memberikan suatu kewajiban pada seseorang atau organisasi, memberikan kewenangan atau hak pada mereka (Een beschikking is een individuele of concrete publiekrechtelijke rechtsbeslissing: een beslissing van een bestuursorgaan, gebaseerd op een publiek-rechtelijke

bevoegheid...geschapen voor een of meer individuen of met betrekking tot een of meer concrete zaken of situaties. Die beslissing verplicht mensen of organisaties tot iets, geeft ze bevoegdheden of geeft ze aanspraken) (Philipus M. Hadjon );

11) R.J.H.M. Huisman secara umum mendefinisikannya sebagai suatu keputusan yang berasal dari organ pemerintahan yang ditujukan untuk menimbulkan akibat hukum (Onder 'beschikking' kan in zijn algemeenheid worden verstaan: een besluit afkomstig van ten bestuursorgaan, dat gericht is op rechtsgevolg) (Philipus M. Hadjon );

12) Sjachran Basah mendefinisikan beschikking adalah keputusan tertulis dari administrasi negara yang mempunyai akibat hukum, untuk menyelenggarakan pemerintahan (dalam arti kata sempit). Ketetapan menentukan situasi hukum yang konkrit dan mempunyai akibat hukum. Sehingga, ketetapan mengandung validitas, daya ikat dan laku yang menimbulkan akibat hukum dari obyek yang diaturnya terhadap yang dikenai suatu peristiwa hukum yang nyata, individual, kasuistik, kondisional dan prioritas dalam hukum administrasi negara (Sjahran Basah; 1989;21);

13) T. Boestomi mendefinisikan beschikking sebagai sarana untuk pelaksanaan tugas mereka, yang lapangan kerjanya adalah bidang pemerintahan (bestuur dalam arti sempit) (Sjachran Basah;1997;122);

14) Rochmat Soemitro mendefinisikannya sebagai penetapan tertulis oleh badan atau pejabat administrasi negara (pegawai negara yang menjabat fungsi negara tertentu), yang berisi suatu tindakan hukum (rechts handeling), berdasarkan peraturan perundang-undangan yang berlaku, bersifat konkrit, individual dan final, dan menimbulkan akibat hukum (hak dan kewajiban yang bersifat individual), baik bagi seseorang atau badan hukum tertentu (Soemitro; 1987).

15) E. Utrecht memberikan definisi beschikking adalah perbuatan hukum publik bersegi satu (yang dilakukan oleh alat-alat pemerintahan berdasarkan suatu kekuasaan istimewa). Keputusan merupakan perbuatan pemerintahan dalam arti kata luas yang khusus bagi lapangan pemerintahan dalam arti kata sempit (de specifieke bewindshandeling op het terein van bestuur) (Utrecht). 
16) Soehino: perbuatan hukum alatalat perlengkapan administrasi negara yang dilakukan berdasarkan wewenang yang diberikan kepadanya oleh aturan hukum inabstrakto dan unpersonal, berupa pembentukan aturan hukum inkonkrito mengenai suatu hal yang konkrit, dan terhadap subyek hukum yang konkrit (Soehino; 2000; 55).

17) Paulus Effendi Lotulung: produk yang diterbitkan oleh pejabat tata usaha negara (atau jabatan tata usaha negara) berdasarkan wewenang yang ada padanya (attributie) atau diberikan padanya dalam bidang urusan pemerintah (Lotulung;2013;27).

(delegate)

18) M. Nata Saputra: perbuatan hukum bersegi satu oleh alat pemerintahan berdasarkan suatu kekuasaan istimewa. Keputusan ini dibuat untuk menyelenggarakan hubungan dalam lingkungan alat negara (staatsorgaan) yang membuatnya (keputusan intern, interne beschikking), dan hubungan antara alat negara dengan seseorang swasta atau antara dua atau lebih alat negara (keputusan ekstern, externe beschikking) (Saputra; 1988; 44).

19) S.F. Marbun: perbuatan hukum publik bersegi satu yang dilakukan alat pemerintah (arti sempit), berdasarkan wewenang istimewa yang dimaksudkan untuk terjadinya perubahan hubungan hukum (Marbun; 2012; 189).

20) Bachsan Mustafa : tindakan hukum publik yang bersegi satu oleh badan administrasi negara. Ditambahkan olehnya, bahwa keputusan dapat dibuat untuk mengatur hubungan dalam lingkungan badan pemerintah (keputusan intern), dan keputusan yang dibuat untuk mengatur hubungan keluar lingkungan badan pemerintah (keputusan ekstern), yang merupakan keputusan yang mengatur hubungan antara pemerintah dengan seorang warga negara, atau dengan suatu badan swasta atau antara dua atau lebih badan pemerintah (Bachsan Mustafa).

21) van Vollenhoven: suatu perbuatan hukum yang bersifat sebelah pihak, dalam lapangan pemerintahan dilakukan oleh suatu badan pemerintah berdasarkan kekuasaannya yang istimewa (Pudyatmoko\&Tjandra; 1996; 32).

Berdasarkan pendapat para ahli di atas, maka keputusan administrasi negara menurut Penulis dapat dijabarkan sebagai tindakan hukum bersegi satu (tindakan yang dilakukan secara sepihak oleh pemerintah yang bukan suatu persetujuan dua pihak). Tindakan ini adalah dalam arti luas, yang khusus bagi lapangan pemerintahan dalam arti kata sempit (menyelenggarakan pemerintahan dan pelaksanaan tugas pemerintahan dalam arti sempit (bestuur)), dan alat pemerintah dalam arti luas, di luar lapangan pembuatan peraturan, polisi, dan pengadilan (pembagian kekuasaan, functieverdeling).

Keputusan administrasi negara ini merupakan pernyataan keluar kehendak (perintah adalah pernyataan kehendak pemerintah yang ditujukan kepada seseorang atau beberapa orang yang tegas 
disebutkan siapa-siapa dan bagi orang itu, dan pernyataan kehendak tersebut melahirkan kewajiban tertentu yang sebelumnya tidak dipikul (W. F. Prins\&R. Kosim Adisapoetra;84) administrasi negara dari pejabat administrasi negara yang berwenang dalam bidang pemerintahan atau urusan pemerintahan (delegate). Wewenang luar biasa ini adalah berdasarkan hukum publik atau merupakan realisasi ketentuan undang-undang (hukum publik, berdasarkan peraturan hukum tata negara atau administrasi negara, atau wewenang atribusi), sehingga tindakan hukumnya tersebut menjadi bersifat istimewa (kekuasaan istimewa).

Keputusan administrasi negara bentuknya dapat tertulis ataupun tidak tertulis, bersifat sebagai administrasi negara, nyata atau konkrit (kasuistik, Peristiwa khusus, pembentukan aturan hukum inkonkrito), individual (berlaku terhadap seseorang atau badan hukum tertentu), dan final (menimbulkan akibat hukum, dengan maksud menentukan hak dan kewajiban). Keputusan administrasi negara tersebut mengatur hubungan hukum yang telah ada atau untuk menimbulkan suatu hubungan hukum yang baru. Pengubahan atau pencabutan hubungan hukum, baik yang belum berlaku maupun yang telah berlaku, yang juga mengandung validitas, memiliki daya ikat dan daya laku, kondisional, serta bersifat prioritas dalam hukum administrasi negara kepada pemohon keputusan. Keputusan administrasi negara yang mengatur hubungan hukum antara pemerintah dengan seseorang atau badan hukum perdata, termasuk hubungan hukum antara dua atau lebih badan pemerintah (dibuat untuk hubungan intern dan ekstern), termasuk pula pengertian keputusan administrasi negara di sini adalah keputusan administrasi negara negatif.

Unsur-unsur keputusan administrasi negara dalam doktrin dapat diuraikan sebagai berikut (Soetomo;1981) :

1) Pernyataan keluar kehendak dari administrasi negara.

2) Oleh pejabat yang berwenang.

3) Bentuknya tertulis

4) Tindakan hukum bersegi satu (tindakan yang dilakukan secara sepihak oleh pemerintah yang bukan suatu persetujuan dua pihak).

5) Bersifat administrasi negara.

6) Dalam bidang pemerintahan atau urusan pemerintahan.

7) Wewenang luar biasa yang berdasarkan hukum publik atau merupakan suatu realisasi dari ketentuan undang-undang (hukum publik, baik berdasarkan peraturan hukum tata negara atau administrasi negara, atau merupakan wewenang atribusi), sehingga tindakan hukumnya bersifat istimewa (kekuasaan istimewa).

8) Sifatnya nyata atau konkrit (kasuistik, peristiwa khusus, Pembentukan aturan hukum inkonkrito), individual (seseorang atau badan hukum tertentu), dan final (Menimbulkan akibat hukum atau dengan maksud menentukan hak dan kewajiban), baik suatu hubungan hukum yang telah ada atau untuk menimbulkan suatu hubungan hukum yang baru, pengubahan atau 
pencabutan hubungan hukum baik belum maupun yang telah berlaku.

9) Mengandung validitas, daya ikat dan laku, kondisional dan prioritas dalam hukum administrasi negara.

10) Ditujukan kepada pemohon keputusan.

11) Suatu tindakan dalam arti luas yang khusus bagi lapangan pemerintahan dalam arti kata sempit (menyelenggarakan

pemerintahan dan pelaksanaan tugas pemerintahan dalam arti sempit (bestuur), dan alat pemerintah dalam arti luas, diluar lapangan pembuatan peraturan, polisi dan militer, dan pengadilan (pembagian kekuasaan).

12) Suatu hubungan hukum antara pemerintah dengan seseorang atau badan hukum perdata, termasuk hubungan hukum antara dua atau lebih badan pemerintah (hubungan hukum intern dan ekstern).

13) Termasuk keputusan negatif.

Berdasarkan pandangan dari para ahli seperti tersebut di atas, penulis berpendapat, bahwa keputusan administrasi negara, termasuk keputusan negatif, adalah pernyataan keluar kehendak pemerintah yang diberikan kepada jabatan di dalam pemerintahan secara sepihak, yang digunakan untuk melaksanakan tugas dan fungsi administrasi negara secara senyatanya oleh pejabat administrasi negara, yang mana tindakan tersebut merupakan tindakan hukum publik yang berdasarkan dan/atau diberikan oleh undang-undang yang bersifat sebagai hukum publik untuk suatu peristiwa konkrit dan final kepada seseorang atau badan hukum perdata. Dengan demikian, maka secara lebih singkat unsur-unsur keputusan administrasi negara menurut penulis adalah:

1. Pernyataan keluar kehendak pemerintah.

2. Dilakukan secara sepihak

3. Bertujuan melaksanakan tugas dan fungsi administrasi negara.

4. Dilakukan oleh pejabat administrasi negara.

5. Merupakan Tindakan hukum publik.

6. Berdasarkan dan/atau diberikan oleh undang-undang yang sifatnya hukum publik.

7. Untuk peristiwa konkrit dan final.

8. Ditujukan kepada seseorang atau badan hukum perdata.

9. Termasuk pula didalamnya adalah keputusan negatif.

\section{Keputusan Administrasi yang Sah}

Sifat norma hukum keputusan administrasi negara adalah individual dan konkrit, dan dalam hirarki norma hukum, bersifat sebagai norma penutup. Stellinga memandang, bahwa kekuatan hukum suatu keputusan administrasi negara tersebut, pengaruhnya adalah terhadap lingkungan kerja, sedangkan sahnya suatu keputusan ini berkenaan dengan suatu perbuatan pemerintah.

Perbuatan pemerintah menjadi sah apabila dapat diterima sebagai bagian dari ketertiban hukum, dan mempunyai kekuatan hukum apabila dapat mempengaruhi pergaulan hukum. Terhadap hal ini, A.M. Donner berpendapat bahwa keputusan administrasi negara yang mempunyai kekurangan yuridis, masih dapat 
berlaku sebagai keputusan sah sampai waktu pembatalannya. Selain itu, suatu keputusan administrasi negara yang tidak mempunyai kekurangan yuridis hanya berlaku sementara selama belum dibatalkan/ditarik, bahkan dapat dibatalkan (ditarik kembali), apabila pembuatnya tidak bijaksana (ditinjau dari segi doelmatigheid).

Hal demikian, terjadi apabila subyek yang dikenai keputusan itu mengajukan banding. Pengajuan banding yang diterima, akan menjadikan keputusan itu menjadi tidak sah, dan jika ditolak, maka menjadikan keputusan itu berlaku definitif (mempunyai kekuatan hukum formal). Terkait hal ini, Nata Saputra menyatakan bahwa kekuatan hukum keputusan dapat dibagi atas kekuatan hukum formal (formele rechtskracht) dan kekuatan hukum materiil (materiele rechtskracht) (Nata Saputra;58-63).

Keputusan yang sah (rechtsgeldig) menurut Utrecht, tentu akan mendapat kekuatan hukum (rechtskracht). Keputusan yang sah tersebut merupakan perbuatan pemerintah yang dapat diterima sebagai suatu bagian dari ketertiban hukum umum (als een onderdeel van de algemene rechtsorde). Perihal sah tersebut, tidak berkenaan dengan isi atau kekurangan dalam perbuatan pemerintah, namun dengan pengertian bahwa telah diterima sebagai suatu yang berlaku pasti.

Perbuatan yang diterima sebagai sesuatu yang berlaku pasti (diterima sebagai bagian dari ketertiban hukum umum), maka perbuatan pemerintah tersebut akan mempunyai kekuatan hukum, yang tentunya akan mempengaruhi ketertiban hukum. Oleh karenanya, sebelum dinyatakan sah, maka perbuatan pemerintah belumlah memiliki kekuatan hukum, sehingga belum dapat mempengaruhi ketertiban hukum yang berlaku (geldende rechtsorde) (Utrecht; 163164).

Sah menurut Stellinga, adalah pendapat tentang suatu perbuatan pemerintah. Sebagaimana penjelasan sebelumnya di atas, bahwa perbuatan pemerintah sah, apabila dapat diterima sebagai suatu bagian dari ketertiban hukum. Dan Perbuatan pemerintah mempunyai kekuatan hukum, apabila dapat mempengaruhi pergaulan hukum. Berbeda dengan perbuatan pemerintah yang harus disetujui atau dibandingkan (oleh alat negara yang lebih tinggi) sebelum dapat berlaku (sebagai bagian dari ketertiban hukum). Perbuatan pemerintah yang disetujui atau diteguhkan (dikuatkan) dalam bandingan, oleh karena dapat diterima sebagai suatu perbuatan sah, maka sahnya perbuatan itu telah ada sejak permulaan. Namun sahnya tersebut masih perlu dinyatakan dengan tegas. Setelah dinyatakan dengan tegas (oleh persetujuan alat pemerintah yang lebih tinggi atau dalam bandingan), maka perbuatan yang demikian dapat dikatakan telah mendapatkan kekuatan hukum (Utrecht;164).

\section{Penutup \\ Simpulan}

Keputusan administrasi negara merupakan tindakan hukum sepihak oleh pemerintah, yang kewenangannya diberikan kepada jabatan yang ada di dalamnya, dan dilaksanakan secara senyatanya (konkritisasi) oleh pejabatnya berdasarkan ketentuan hukum positif 
yang sifatnya konkrit, individual, dan final. Tindakan hukum merupakan suatu tindakan yang dapat dikaitkan dengan hukum atau terdapat relevansi hukum di dalamnya, sedangkan sepihak diartikan sebagai suatu tindakan yang tidak memerlukan persetujuan dari pihak lain ketika akan dilakukan.

Pemerintah

merupakan gabungan jabatan-jabatan (complex van ambten) yang diberikan kewenangan untuk melaksanakan kehendak pemerintah. Oleh karenanya, pemerintah dan jabatan merupakan konstruksi yuridis, yang kewenangannya hanya dapat dilakukan secara nyata oleh pejabat yang menduduki jabatan itu (konkritisasi). Keputusan administrasi negara menunjuk pada suatu peristiwa hukum tertentu (konkrit), dan ditujukan kepada seseorang atau badan hukum perdata (individual). Sedangkan, untuk kata final, artinya tidak memerlukan lagi persetujuan dan/atau peneguhan dari pejabat administrasi negara yang lainnya untuk berlaku, sehingga secara mutatis mutandis telah menimbulkan suatu akibat hukum (hak dan kewajiban) bagi yang dituju keputusan tersebut.

\section{Saran}

Bagi pemerintah, perlu memahami bahwa dinamika merupakan suatu keniscayaan bagi pemerintahan dan masyarakat di dalam kehidupan kenegaraan, yang secara terus menerus berubah, dan saling mempengaruhi satu sama lainnya. Keputusan administrasi negara merupakan ketentuan positif (baca: norma penutup) yang merupakan pedoman validitas bagi pemerintah dalam bertindak di lain sisi, sedangkan lain sisinya merupakan bentuk perlindungan hukum bagi masyarakat terhadap tindakan pemerintah.

Secara konseptual, norma positif selalu hanya akan menjadi sekedar moment opname saja, tidak dapat secara utuh menjawab segala kepentingan yang ada di dalam masyarakat, sedangkan masyarakat dengan cepat berubah secara dinamis. Dengan demikian, doktrin seharusnya menjadi perangkat konseptual memberikan petunjuk yang utuh bagi tindakan pemerintah membuat keputusan administrasi negara, yang sekaligus juga merupakan salah satu bentuk perlindungan hukum bagi masyarakat (rechtsbescherming).

\section{Daftar Pustaka}

Atmadja, Arifin P. Soeria, 1986, Mekanisme

Pertanggungjawaban Keuangan Negara: Suatu Tinjauan Yuridis, PT. Gramedia, Jakarta.

Atmosudirjo, S. Prajudi, 1994, Hukum Administrasi Negara, Edisi Revisi; Seri Pustaka Ilmu Administrasi Negara VII, Ghalia Indonesia, Jakarta.

Basah, Sjachran, 1989, Hukum Acara Pengadilan dalam Lingkungan Peradilan Administrasi (HAPLA), Rajawali Pers, Jakarta.

Basah, Sjacran, 1997, Eksistensi dan Tolak Ukur Badan Peradilan Administrasi di Indonesia, Alumni, Bandung.

Hadjon, Philipus M., dkk, 2002, Pengantar Hukum Administrasi Indonesia, Gadjah Mada University Press, Yogyakarta.

HR., Ridwan, 2011, Hukum Administrasi Negara; Edisi 
Revisi, rajagrafindo Persada, Jakarta.

Jeddawi, Murtir, 2012, Hukum Administrasi Negara, Total Media, Yogyakarta.

Lotulung, Paulus Effendi, 2013, Hukum Tata Usaha Negara dan Kekuasaan, Salemba Humanika, Jakarta.

Marbun, S.F., 2012, Hukum Administrasi Negara I, FH UII Press, Yogyakarta.

Mustafa, Bachsan, 2001, Sistem Hukum Administrasi Negara Indonesia, Citra Aditya Bakti, Bandung.

Poerbopranoto, Koentjoro, 1981, Perkembangan Hukum Administrasi Indonesia, Binacipta, Bandung.

Prins W.F., dan R. Kosim Adisapoetra, 1987, Pengantar Hukum Administrasi Negara, Pradnya Paramita, Jakarta.

Pudyatmoko, Y. Sri, dan W. Riawan Tjandra, 1996, Peradilan Tata Usaha Negara Sebagai Salah Satu Fungsi Kontrol Pemerintah, Penerbitan Universitas Atma Jaya Yogyakarta, Yogyakarta.

Saputra, M. Nata, 1988, Hukum Administrasi Negara, Rajawali, Jakarta.

Sekretariat Jenderal Dewan Perwakilan Rakyat Republik Indonesia, 2008, Proses Pembahasan Rancangan Undang-Undang tentang Peradilan Umum dan Tata Usaha Negara, Jakarta.

Soehino, 2000, Asas-asas Hukum Tata Usaha Negara, Liberty, Yogyakarta.

Soemitro, Rochmat, 1987, Peradilan Tata Usaha Negara, Eresco, Bandung.
Soetomo, 1981, Pengantar Hukum Tata Pemerintahan, Lembaga Penerbitan Universitas Brawijaya, Malang.

Sudarsono, 1994, Pengadilan Negeri, Pengadilan Tinggi, Mahkamah Agung, dan Peradilan Tata Usaha Negara, PT. Rineka Cipta, Jakarta.

Tjandra, W. Riawan, 2010, Teori Dan Praktik Peradilan Tata Usaha Negara, Penerbit Universitas Atma Jaya, Yogyakarta.

Utrecht, E., 1986, Pengantar Hukum Administrasi Negara Indonesia, Tinta Mas, Surabaya. 